\title{
PENGARUH NORMA SUBJEKTIF, KESADARAN WAJIB PAJAK, KUALITAS PELAYANAN DAN SANKSI PERPAJAKAN TERHADAP KEPATUHAN WAJIB PAJAK KENDARAAN BERMOTOR DI SAMSAT KABUPATEN PEMALANG
}

\author{
Dhalifah Nur Rohmah \\ Program Studi Akuntansi \\ Fakultas Ekonomi dan Bisnis Universitas Pancasakti
}

\begin{abstract}
This study aims to determine the Influence of Subjective Norms, Taxpayer Awareness, Service Quality and Tax Sanctions on Compliance of Motorized Taxpayers on SAMSAT Pemalang District. This study uses primary data obtained from respondents' answers to the questionnaires used in the study. Data analysis method uses Descriptive Statistics, Testing Instrument Research, Classical Assumption Test, Multiple Regression Analysis, Hypothesis Test and Determination Coefficient. Research results show that the F test of subjective norm variables, taxpayer awareness, service quality and tax sanctions affect simultaneously on motor vehicle taxpayer compliance in SAMSAT Pemalang District. Partially, the Subjective Norm variable does not significantly influence the Motor Vehicle Taxpayer Compliance variable, the variable of Taxpayer Awareness has a significant influence on Motor Vehicle Taxpayer Compliance, Service Quality variable has a significant effect on Motor Vehicle Taxpayer Compliance, Tax Sanction variable does not significantly influence Motor Vehicle Taxpayer Compliance.
\end{abstract}

Keywords: Subjective Norms, Taxpayer Awareness, Service Quality Tax Sanctions, Taxpayer Compliance

\section{PENDAHULUAN}

Pajak merupakan sarana atau alat penghasilan negara yang dikelola pemerintah dalam aspek pembangunan guna meningkatkan angka kesejahteraan masyarakat. Salah satu aspek penunjang dalam keberhasilan pembangunan nasional tersebut diambil dari sumber daya alam, sumber daya manusia, dan sumber daya lainnya. Yang mana semuanya itu merupakan ketersediaan dana pembangunan baik diperoleh dari sumber pajak maupun non pajak (Nugroho, 2016). Pembangunan daerah tidak akan berjalan tanpa adanya sumber pembiayaan yang memadai. Oleh karena itu pembiayaan menjadi modal utama guna terlaksananya pembangunan daerah, dan juga pembiayaan menjadi masalah yang sangat vital, dimana sumber pembiayaan daerah tergantung kepada penerimaan daerah. (Utama dalam Efendy, 2015).

Pajak Kendaraan bermotor (PKB) merupakan jenis pemungutan yang sudah lama dilakukan oleh pemerintah daerah sebagai salah satu sumber pendapatan asli daerah, yang digunakan untuk membiayai pelaksanaan tugas rutin pemerintah daerah (Yunus, 2010). Instansi yang menangani Wajib Pajak membayar Pajak Kendaraan Bermotor adalah Dinas Pendapatan Dan Pengelolaan Aset Daerah (DPPAD) melalui Kantor Bersama Sistem Administrasi Manunggal di Bawah Satu Atap (SAMSAT) yang merupakan 
yang merupakan kerjasama 3 instansi terkait yaitu DPPAD Provinsi Jawa Tengah, Kepolisian RI, dan Asuransi Jasa Raharja. Besarnya penerimaan Pajak Kendaraan Bermotor diukur dengan peredaran jumlah kendaraan bermotor yang semakin tinggi dari tahun ke tahun (Chasanah, 2016).

Fenomena yang terjadi saat ini di Kabupaten Pemalang dikemukakan oleh Sugiarto selaku anggota Komisi C DPRD Jawa Tengah bahwa pada tahun 2017 tunggakan pajak roda empat mencapai 2.017 unit senilai $\mathrm{Rp} 2.212$ miliar. Keadaan hingga 25 September telah tertagih sebanyak 427 kendaraan senilai Rp 767 juta lebih sedangkan roda 2 mencapai 40.476 unit senilai Rp 6.392 miliar, yang berhasil ditagih mencapai 9.777 unit senilai Rp 2.104 miliar. Melihat keadaan tersebut pihak UPPD dan SAMSAT kabupaten pemalang dituntut untuk terus mengatasi tunggakan demi pencapaian target.

Kondisi perpajakan dalam menyelenggarakan perpajakannya menuntut keikutsertaan aktif wajib pajak yaitu dibutuhkan kepatuhan dalam pemenuhan kewajiban perpajakannya. Wajib pajak patuh yaitu wajib pajak yang taat akan peraturan pajak dengan memenuhi serta melaksanakan kewajiban perpajakannya (Rahayu, 2017:193). Kepatuhan Wajib Pajak menjadi masalah yang penting baik itu di negara maju maupun di negara berkembang, Wajib Pajak yang tidak patuh cenderung mempunyai keinginan untuk melakukan tindakan penghindaran, pengelakan dan pelalaian pajak (Sari, 2013). Tingkat kepatuhan wajib pajak tidak hanya bersumber dari dalam diri individu seseorang, melainkan dipengaruhi oleh individu lain atau bahkan kelompok lingkungan yang berada disekitar wajib pajak, yang dapat disebut dengan norma subjektif (Dharmawan, 2015).
Norma subjektif merupakan persepsi yang bersifat individual terhadap tekanan sosial untuk melakukan atau tidak melakukan perilaku tertentu. Seorang individu akan melakukan suatu perilaku tertentu yang dilakukan orang lain apabila persepsi orang lain terhadap perilaku tersebut bersifat positif. Indikator subjektif tersebut antara lain yaitu anggota keluarga, pimpinan perusahaan, teman, pasangan (Alvin, 2014).

Kepatuhan wajib pajak dapat dilihat dari kesungguhan dan keinginan wajib pajak untuk memenuhi kewajiban pajaknya yang ditunjukkan dalam pemahaman wajib pajak terhadap fungsi pajak dan kesungguhan wajib pajak dalam membayar dan melaporkan pajak (Yasa, 2017). Kesadaran dan kepedulian sukarela Wajib Pajaksampai saat ini sulit untuk diwujudkan. Umumnya masyarakat masih sinis dan kurang percaya terhadap keberadaan pajak karena masih merasa sama seperti upeti, memberatkan, pembayarannya sering mengalami kesulitan, serta kurangnya pemahaman masyarakat tentang pajak (Irianingsih, 2015).

Menumbuhkan kesadaran pada Wajib Pajak memang tidak mudah. Bahkan pada contoh kasus lain mereka cenderung meloloskan diri dari kewajibannya membayar pajak. Ada banyak faktor yang menyebabkan tingkat kesadaran masyarakat masih rendah diantaranya adalah kurangnya informasi dari pemerintah kepada rakyat, adanya kebocoran dalam sistem penerimaan pemungutan pajak, malas, dan tidak adanya timbal balik secara langsung dari pemerintah. Cara pemungutan pajak yang sesuai juga mempengaruhi wajib pajak dalam kewajibannya membayar pajak (Nugroho, 2016).

Upaya pemerintah dalam meningkatkan jumlah pendapatan dari 
sektor pajak salah satunya dengan cara meningkatkan kepuasan wajib pajak melalui pemberian kualitas pelayanan yang optimal. Peningkatan kualitas dan kuantitas pelayanan diharapkan berdampak pada kepatuhan dan kesadaran wajib pajak dalam membayar atau melunasi kewajiban membayar pajak kendaraan bermotor (Hermawan, 2016). Selain kualitas pelayanan yang baik dalam peraturan pajak kendaraan bermotor terdapat penegakan hukum yaitu diwujudkan melalui pemberian sanksi perpajakan. Sanksi pajak memiliki peran penting untuk mencegah ketidakpatuhan serta memberikan pelajaran bagi pelanggar pajak dan untuk mendorong wajib pajak agar tidak meremehkan peraturan perpajakan dan untuk memajukan keadilan dan efektivitas sistem pajak (Yasa, 2017). Oleh karena itu, dengan adanya sanksi pajak diharapkan wajib pajak patuh terhadap peraturan perpajakan guna meminimalisir pelanggaran serta berusaha untuk memenuhi kewajibannya karna sanksi pajak akan merugikannya (Jatmiko dalam Ardyanto, 2014). Berdasarkan uraian latar belakang yang telah dijelaskan diatas peneliti tertarik untuk melakukan penelitian di tempat lain guna mengetahui bagaimana kepatuhan masyarakat dalam membayar pajak kendaraan bermotor, sehingga peneliti mengambil judul "Pengaruh Norma Subjektif, Kesadaran Wajib Pajak, Kualitas Pelayanan dan Sanksi Perpajakan terhadap Kepatuhan Wajib Pajak Kendaraan Bermotor di SAMSAT Kabupaten Pemalang".

\section{KERANGKA PEMIKIRAN DAN HIPOTESIS}

Penelitian ini bertujuan untuk mengetahui pengaruh norma subjektif, kesadaran wajib pajak, kualitas pelayanan dan sanksi perpajakan terhadap kepatuhan wajib pajak kendaraan bermotor.

Norma Subjektif, Kesadaran Wajib Pajak, Kualitas Pelayanan dan Sanksi Perpajakan berpengaruh secara simultan terhadap Kepatuhan Wajib Pajak Kendaraan Bermotor.

Norma Subjektif dapat diartikan sebagai sebuah pengaruh yang berasal dari keyakinan seseorang mengenai apa yang harus dilakukan menurut pikiran orang lain beserta motivasinya untuk memenuhi harapan tersebut (Yuliana: 2014). Dengan adanya norma subjektif atau pengaruh serta dorongan yang positif dari luar seseorang maka minat seseorang dalam membayar pajak semakin tinggi (Alvin, 2014).

Kesadaran tinggi yang dimiliki Wajib Pajak juga merupakan peran penting dalam kepatuhan membayar pajak (Faiza, 2016). Pelayanan yang berkualitas akan memberikan kepuasan kepada wajib pajak serta mendorong wajib pajak untuk memenuhi kewajiban perpajakannya kembali (Masruroh, 2013). Adanya sanksi pajak dapat memberikan efek jera bagi wajib pajak yang melanggar norma perpajakan (Arnanto, 2017).

H1. Diduga Norma Subjektif Kesadaran Wajib Pajak, Kualitas Pelayanan dan Sanksi Perpajakan berpengaruh secara simultan terhadap Kepatuhan Wajib Pajak Kendaraan Bermotor.

Pengaruh Norma Subjektif Secara Parsial Terhadap Kepatuhan Wajib Pajak Dalam Membayar Pajak Kendaraan Bermotor

Norma Subjektif menjadi referents bagi Wajib Pajak untuk berlaku patuh atau tidak patuh 
terhadap pajak. Kepatuhan seseorang terhadap aturan perpajakan tidak hanya dipengaruhi oleh diri wajib pajak itu sendiri, akan tetapi dari lingkungan atau dari individu lain seperti teman, pengaruh konsultan pajak, dan pengaruh petugas pajak. Pihak-pihak tersebut disebut sebagai pihak pemberi acuan Wajib Pajak untuk patuh atau tidak patuhnya terhadap peraturan perpajakan, bahkan bisa lebih kuat mempengaruhi Wajib Pajak dibandingkan pengaruh dari dalam diri Wajib Pajak tersebut (Suryani 2017).

H2. Diduga Norma Subjektif secara parsial berpengaruh terhadap kepatuhan wajib pajak kendaraan bermotor di Kabupaten Pemalang

Pengaruh Kesadaran Wajib Pajak Secara Parsial terhadap Kepatuhan Wajib Pajak Dalam Membayar Pajak Kendaraan Bermotor

Dengan adanya kesadaran wajib pajak diharapkan wajib pajak memahami dan menyadari tentang pentingnya peran perpajakan, tetapi hal tersebut belum dapat meningkatkan kepatuhan wajib pajak dalam membayar pajak kendaraan bermotor wajib pajak harus benar-benar menyadari ketentuan perpajakan dengan baik agar dapat menentukan kebijakan dalam pelaksanaan perpajakannya agar tidak melanggar aturan yang ada dalam perundang-undangan perpajakan (Irianingsih, 2015).

H3. Diduga Kesadaran Wajib Pajak secara parsial berpengaruh terhadap kepatuhan wajib pajak kendaraan bermotor di Kabupaten Pemalang
Pengaruh Kualitas Pelayanan Secara Parsial terhadap Kepatuhan Wajib Pajak Dalam Membayar Pajak Kendaraan Bermotor

Pelayanan yang berkualitas akan memberikan kepuasan kepada wajib pajak serta mendorong wajib pajak untuk memenuhi kewajiban perpajakannya kembali. Semakin baik kualitas pelayanan yang diberikan oleh aparat pajak maka wajib pajak akan merasa puas sehingga wajib pajak akan patuh. Demikian pula sebaliknya, semakin buruk kualitas pelayanan pajak maka wajib pajak akan cenderung untuk tidak patuh (Masruroh, 2013).

H4. Diduga Kualitas Pelayanan secara parsial berpengaruh terhadap kepatuhan wajib pajak kendaraan bermotor di Kabupaten Pemalang

Pengaruh Sanksi Perpajakan Secara Parsial terhadap Kepatuhan Wajib Pajak Dalam Membayar Pajak Kendaraan Bermotor

Penerapan sanksi pajak bertujuan membuat efek jera sehingga Wajib pajak akan patuh dan tidak mengulanginya lagi. Semakin banyaknya wajib pajak yang memandang bahwa sanksi denda akan lebih merugikannya, maka semakin tinggi pula tingkat kepatuhan wajib pajak kendaraan bermotor (Ummah, 2015).

H5. Diduga Sanksi Perpajakan secara parsial berpengaruh terhadap kepatuhan wajib pajak kendaraan bermotor di Kabupaten Pemalang 


\section{METODE PENELITIAN}

Pemilihan Metode

Penelitian ini menggunakan metode penelitian kuantitatif yaitu metode yang memerlukan data berupa angka-angka dan pemecahan masalah atau analisis datanya menggunakan teknik statistik (Jauhari: 2010).

\section{Lokasi Penelitian}

Penelitian ini dilakukan Kantor Samsat Wilayah 1 Kabupaten Pemalang yang berlokasi di Jalan Pemuda No. 49 Pemalang.

\section{Teknik Pengambilan Sampel}

Populasi yang akan digunakan dalam penelitian ini adalah seluruh wajib pajak yang terdaftar pada kantor SAMSAT Wilayah 1 Kabupaten Pemalang. Jumlah populasi dalam penelitian ini adalah 32.161 wajib pajak.

Teknik yang digunakan dalam penentuan sampel dalam penelitian ini menggunakan metode accidental sampling. Dimana dalam penentuan sampel ini berdasarkan kebetulan, yaitu siapa saja yang secara kebetulan bertemu dengan peneliti dapat digunakan sebagai sampel, serta bila yang ditemui itu cocok sebagai sumber data maka akan dilakukan pengambilan informasi. Jumlah sampel yang digunakan dalam penelitian ini adalah100 wajib pajak menggunakan rumus slovin.

\section{Definisi Konseptual dan Operasional Variabel}

\section{Definisi Konseptual}

Penelitian ini terdiri dari variabel dependen yaitu kepatuhan wajib pajak sedangkan variabel independen dalam penelitian ini adalah norma subjektif, kesadaran wajib pajak, kualitas pelayanan dan sanksi perpajakan. Definisi konseptual dari masingmasing variabel adalah sebagai berikut:

Kepatuhan Wajib Pajak

Kepatuhan perpajakan merupakan ketaatan wajib pajak dalam melaksanakan ketentuan perpajakan yang berlaku. Wajib pajak yang patuh adalah wajib pajak yang taat memenuhi kewajiban perpajakan sesuai ketentuan peraturan perundang-undangan (Rahayu, 2017).

\section{Norma Subjektif}

Norma subjektif merupakan persepsi individu dimana satu atau lebih orang disekitarnya (misalnya, saudara, teman sejawat) untuk menyetujui dan memotivasi individu pada perilaku tertentu. (Ajzen, 1991 dalam Mustikasari, 2007).

\section{Kesadaran Wajib Pajak}

Kesadaran wajib pajak merupakan kondisi dimana wajib pajak mengerti dan memahami arti, fungsi maupun tujuan pembayaran pajak kepada negara. Dengan kesadaran wajib pajak yang tinggi akan memberikan pengaruh kepada meningkatkan kepatuhan pajak yang lebih baik lagi (Rahayu: 2017). 
Kualitas Pelayanan

Kualitas pelayanan merupakan salah satu kemampuan dalam pelayanan yang diberikan kepada wajib pajak yang mencakup pelayanan umum maupun pelayanan administrasi (Hermawan, 2017).

Sanksi Perpajakan

Sanksi perpajakan merupakan jaminan bahwa ketentuan peraturan perundangan perpajakan (norma perpajakan) akan ditaati atau dipatuhi. Dengan kata lain, sanksi perpajakan merupakan alat pencegah (preventif) agar wajib pajak tidak melanggar norma perpajakan (Suandi: 2011).

Operasional Variabel

Tabel 3.1

Definisi Operasional Variabel

\begin{tabular}{|c|c|c|c|}
\hline Variabel & Dimensi & Indikator & Skala \\
\hline $\begin{array}{l}\text { Kepatuhan Wajib } \\
\text { Pajak (Y) }\end{array}$ & $\begin{array}{l}\text { 1. Kepatuhan Formal } \\
\text { 2. Kepatuhan Material }\end{array}$ & $\begin{array}{l}\text { 1. Tepat waktu dalam melakukan } \\
\text { pembayaran pajak kendaraan } \\
\text { bermotor } \\
\text { 2. Tidak pernah dijatuhi hukuman yang } \\
\text { berkenaan dengan pajak } \\
\text { 3. Tidak mempunyai tunggakan pajak } \\
\text { 1. Tidak pernah melanggar undang- } \\
\text { undang } \\
\text { 2. Mengetahui informasi mengenai } \\
\text { tempat dan cara pembayaran } \\
\text { 3. Memahami kewajiban membayar } \\
\text { pajak }\end{array}$ & Interval \\
\hline $\begin{array}{l}\text { Norma subjektif } \\
\text { (X1) }\end{array}$ & $\begin{array}{l}\text { 1. Lingkungan tempat } \\
\text { tinggal } \\
\text { 2. Pihak eksternal }\end{array}$ & $\begin{array}{l}\text { 1. Pengaruh teman satu profesi } \\
\text { 2. Pengaruh keluarga } \\
\text { 3. Pengaruh lingkungan tempat tinggal } \\
\text { 1. Pengaruh Konsultan Pajak } \\
\text { 2. Pengaruh petugas pajak }\end{array}$ & Interval \\
\hline $\begin{array}{l}\text { Kesadaran Wajib } \\
\text { Pajak (X2) }\end{array}$ & $\begin{array}{l}\text { 1. Fungsi dan manfaat } \\
\text { pajak } \\
\text { 2. Kesadaran dalam diri } \\
\text { Wajib Pajak }\end{array}$ & $\begin{array}{l}\text { 1. Pajak merupakan iuran wajib } \\
\text { 2. Manfaat pajak untuk menunjang } \\
\text { pembangunan } \\
\text { 3. Pajak untuk kesejahteraan masyarakat } \\
\text { 1. Tingkat pengetahuan dalam kesadaran } \\
\text { membayar pajak } \\
\text { 2. Kesadaran warga/masyarakat untuk } \\
\text { membayar pajak secara sukarela } \\
\text { 3. Kondisi keuangan wajib pajak }\end{array}$ & Interval \\
\hline
\end{tabular}


Pengaruh Norma Subjektif, Kesadaran Wajib Pajak,.....

\begin{tabular}{|c|c|c|c|}
\hline Variabel & Dimensi & Indikator & Skala \\
\hline $\begin{array}{l}\text { Kualitas Pelayanan } \\
\text { (X3) }\end{array}$ & $\begin{array}{l}\text { 1. Bukti langsung } \\
\text { (Tangibles) }\end{array}$ & $\begin{array}{l}\text { 1. Kebersihan kenyamanan ruangan. } \\
\text { 2. Kebersihan, kerapihan dan } \\
\text { kenyamanan penampilan pegawai. } \\
\text { 1. Kemampuan menyampaikan } \\
\text { informasi dengan jelas dan mudah } \\
\text { dimengerti } \\
\text { 2. Kemampuan pegawai untuk cepat } \\
\text { tanggap dalam menangani keluhan } \\
\text { Wajib Pajak }\end{array}$ & Interval \\
\hline $\begin{array}{l}\text { Sanksi Perpajakan } \\
\text { (X4) }\end{array}$ & $\begin{array}{l}\text { 1. Pengetahuan sanksi } \\
\text { 2. Sanksi administrasi } \\
\text { 3. Sanksi Pidana }\end{array}$ & $\begin{array}{l}\text { 1. Pengetahuan adanya sanksi } \\
\text { 2. Pengetahuan pentingnya sanksi bagi } \\
\text { wajib pajak } \\
\text { 1. Keterlambatan pembayaran pajak } \\
\text { 2. Sanksi hanya berupa denda dan } \\
\text { bunga } \\
\text { 3. Kesesuaian sanksi dengan undang- } \\
\text { undang. } \\
\\
\text { 1. Kedisiplinan sangat penting untuk } \\
\text { wajib pajak } \\
\text { 2. Sanksi yang dikenakan tanpa } \\
\text { toleransi }\end{array}$ & Interval \\
\hline
\end{tabular}

Sumber: Data Diolah 2018

Teknik Pengumpulan Data

Dalam penelitian ini jenis data yang digunakan adalah data primer. Sumber data primer dalam penelitian ini diperoleh secara langsung dari pengumpulan data hasil pengisian kuesioner wajib pajak yang kendaraannya terdaftar pada SAMSAT Kabupaten Pemalang. Dalam kuesioner tertutup responden diminta untuk memilih jawaban yang sudah disediakan oleh peneliti. Jenis skala yang digunakan untuk menjawab bagian pertanyaan penelitian adalah Skala likert. Menurut Sekaran (2006:31) Skala likert digunakan untuk menelaah seberapa kuat subjek setuju dan tidak setuju pada pernyataan pada skala 5 titik dengan susunan sangat setuju (SS) dengan skor 5, Setuju (S) dengan skor 4, Kurang Setuju (KS) dengan skor 3, tidak setuju (TS) dengan skor 2, dan sangat tidak setuju (STS) dengan skor 1.

\section{Teknik Pengolahan Data}

Teknik pengolahan data yang digunakan dalam penelitian ini adalah teknik pengolahan SPSS versi 23 (Statistical Package for Social Science) untuk mengetahui Pengaruh Norma Subjektif, Kesadaran Wajib Pajak, Kualitas Pelayanan, dan Sanksi Perpajakan Terhadap Kepatuhan Wajib Pajak Kendaraan Bermotor di SAMSAT Kabupaten Pemalang. 
HASIL

Hasil Analisis Data dan Pengujian Hipotesis

Uji Asumsi Klasik

a. Uji Normalitas

Uji Normalitas digunakan untuk mengetahui apakah data yang digunakan dalam model regresi normal dan layak digunakan atau tidak mengenai variabel yang digunakan Untuk menguji apakah distribusi normal atau tidak, pengujian Normalitas data secara analisis statistik dilakukan dengan menggunakan Grafik Histogram sebagai berikut

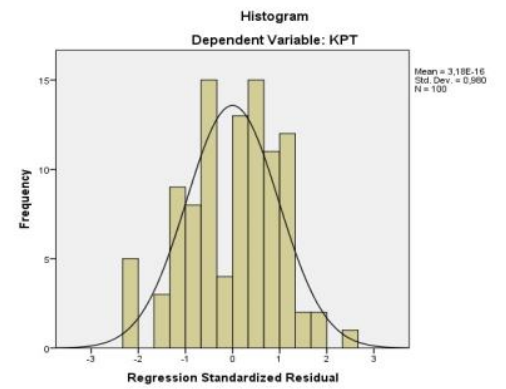

Sumber: Output SPSS23

Gambar 4.1 Hasil Uji

Normalitas

Berdasarkan grafik histogram pada Gambar 4.1 dapat dinyatakan bahwa variabel pengganggu atau residual memiliki distribusi normal.

Uji Multikoloniearitas

Uji Multikolinieritas digunakan untuk mengetahui apakah pada model regresi ditemukan adanya korelasi antar variabel independen. Metode pengujian Multikolonieritas yang digunakan adalah metode VIF (Variance Inflation Factor). Sehingga hasil yang didapatkan dari pengujian Multikolonieritas dapat dilihat pada tabel 4.1 sebagai berikut:

Tabel 4.1

Hasil Uji Multikolinearitas

Coefficients ${ }^{a}$

\begin{tabular}{|c|c|c|c|}
\hline \multirow{2}{*}{\multicolumn{2}{|c|}{ Model }} & \multicolumn{2}{|c|}{ Collinearity Statistics } \\
\hline & & Tolerance & VIF \\
\hline \multirow[t]{4}{*}{1} & NS & .999 & 1,001 \\
\hline & KWP & .879 & 1,137 \\
\hline & $\mathrm{KP}$ & .840 & 1,191 \\
\hline & SP & .923 & 1,084 \\
\hline
\end{tabular}

Sumber: Output SPSS23

Berdasarkan tabel 4.1 menunjukkan bahwa untuk semua variabel independen yaitu Norma Subjektif, Kesadaran Wajib Pajak, Kualitas Pelayanan dan Sanksi Perpajakan masingmasing memiliki angka toleransi diatas nilai 0,1 dan untuk VIF kurang dari nilai 10 sehingga model regresi dinyatakan tidak terjadi gejala multikolonieritas.

Uji Heterokedastisitas

Uji Heteroskedastisitas adalah uji yang digunakan untuk mengetahui apakah dalam sebuah model regresi terjadi ketidaksamaan varians residual dari satu pengamatan ke pengamatan yang lain. variabel yang digunakan. Metode pengujian Heteroskedastisitas yang digunakan adalah Scatterplots. Hasil yang didapatkan dari pengujian Heteroskedastisitas dapat dilihat pada gambar 4.2 sebagai berikut: 
Berdasarkan tabel 4.4 diatas, maka didapatkan model persamaan regresi yaitu

$$
\begin{aligned}
\mathrm{Y}= & 7,480+0,173+0,308+ \\
& 0,286-0,030+\mathrm{e}
\end{aligned}
$$

Dari persamaan tersebut diatas, dapat diartikan bahwa: Nilai konstanta sebesar 7,480 , menyatakan variabel independen kepatuhan wajib pajak kendaraan bermotor, nilai konstanta 7,480 yang dapat diartikan bahwa jika variabel independen Norma Subjektif, Kesadaran Wajib Pajak, Kualitas Pelayanan dan Sanksi Perpajakan dianggap bernilai nol, maka nilai variabel dependen Kepatuhan Wajib Pajak Kendaraan bermotor bernilai 7,480.

Nilai $\beta$ sebesar 0,173 pada variabel Norma Subjektif (X1) memiliki arti bahwa jika variabel Norma Subjektif (X1) mempunyai peningkatan sebesar $1 \%$ maka nilai pada variabel Kepatuhan Wajib Pajak Kendaraan Bermotor (Y) akan meningkat sebesar 0,173 .

Nilai $\beta$ sebesar 0,308 pada variabel Kesadaran Wajib Pajak (X2) memiliki arti bahwa jika variabel Kesadaran Wajib Pajak (X2) mempunyai peningkatan nilai sebesar $1 \%$ maka nilai pada variabel Kepatuhan Wajib Pajak Kendaraan Bermotor (Y) akan meningkat sebesar 0,308 .
Nilai $\beta$ sebesar 0,286 pada variabel Kualitas Pelayanan (X3) memiliki arti bahwa jika variabel Kualitas Pelayanan (X3) mempunyai peningkatan nilai sebesar $1 \%$ maka nilai pada variabel Kepatuhan Wajib Pajak Kendaraan Bermotor (Y) akan meningkat sebesar 0,286 .

Nilai $\beta$ sebesar $-0,030$ pada variabel Sanksi Perpajakan (X4) memiliki arti bahwa jika variabel Sanksi Perpajakan (X4) mempunyai peningkatan nilai sebesar $1 \%$ maka nilai pada variabel Kepatuhan Wajib Pajak Kendaraan Bermotor (Y) akan meningkat sebesar 0,030 .

\section{Pengujian Hipotesis}

Uji Hipotesis F

Uji Hipotesis $F$ digunakan untuk menguji joint hipotesis bahwa $\mathrm{X}_{1}, \mathrm{X}_{2}, \mathrm{X}_{3}$ dan $\mathrm{X}_{4}$ secara simultan berpengaruh terhadap Y. Hasil yang didapatkan dari pengujian Statistik F dapat dilihat pada tabel 4.5 sebagai berikut:

Tabel 4.5

Hasil Uji Hipotesis F

\begin{tabular}{|c|c|c|c|c|c|c|}
\hline Mode & & $\begin{array}{l}\text { Sum of } \\
\text { Squares }\end{array}$ & df & Mean Square & $\mathrm{F}$ & Sig. \\
\hline \multirow[t]{3}{*}{1} & Regression & 230,078 & 4 & 57,520 & 4,663 & $.002^{b}$ \\
\hline & Residual & 1171,962 & 95 & 12,336 & & \\
\hline & Total & 1402,040 & 99 & & & \\
\hline
\end{tabular}

ANOVA $^{a}$

Sumber: Output SPSS23 
Berdasarkan tabel 4.5 hipotesis pertama hasil dari uji hipotesis $\mathrm{F}$ menyatakan bahwa semua variabel yang digunakan dalam penelitian ini yakni Norma Subjektif, Kesadaran Wajib Pajak, Kualitas Pelayanan dan Sanksi Perpajakan secara simultan berpengaruh terhadap Kepatuhan Wajib Pajak Kendaraan Bermotor. Hal tersebut dilihat dari nilai signifikan yang diperoleh sebesar $0,002(0,002<0,05)$ dengan nilai Fhitung yang dihasilkan sebesar 4,663 nilai ini lebih besar daripada nilai Ftabel sebesar 2,47 $(4,663>2,47)$.

Uji Hipotesis t

Uji Hipotesis $t$ Menurut Santoso (2015:75) bertujuan untuk mengetahui apakah sebuah nilai tertentu yang diberikan sebagai pembanding, berbeda secara nyata ataukah tidak dengan ratarata sebuah sampel, dengan tingkat signifikansi 0,05 (5\%). Hasil yang didapatkan dari pengujian Hipotesis $\mathrm{t}$ dapat dilihat pada tabel 4.6 sebagai berikut:

Tabel 4.6

Hasil Uji Hipotesis t

\begin{tabular}{|ll|c|c|}
\hline Model & $\mathrm{t}$ & Sig. \\
\hline 1 & (Constant) & 1,055 &, 294 \\
& NS & 1,640 &, 104 \\
& KWP & 2,235 &, 028 \\
& KP & 2,286 &, 024 \\
SP &,- 200 &, 842 \\
\hline
\end{tabular}

a. Dependent Variable: KPT

Sumber: Output SPSS23
Berdasarkan tabel 4.6 diketahui bahwa pengaruh variabel-variabel independen terhadap variabel dependen sebagai berikut:

Hipotesis Kedua:hasil uji hipotesis $\mathrm{t}$ menyatakan bahwa Norma Subjektif secara parsial tidak berpengaruh terhadap Kepatuhan Wajib Pajak Kendaraan Bermotor. Hal tersebut dilihat dari nilai signifikansi pada variabel Norma Subjektif yaitu sebesar 0,104 (0,104 > $0,05)$.

Hipotesis Ketiga: Kesadaran Wajib Pajak secara parsial berpengaruh terhadap Kepatuhan Wajib Pajak Kendaraan Bermotor. Hal tersebut terbukti dari nilai signifikansi pada variabel Kesadaran Wajib Pajak $0,028(0,028<0,05)$

Hipotesis Keempat: Kualitas Pelayanan secara parsial berpengaruh terhadap Kepatuhan Wajib Pajak Kendaraan Bermotor. Hal tersebut terbukti dari nilai signifikansi pada variabel Kualitas Pelayanan 0,024 $(0,024<0,05)$

Hipotesis Kelima: Sanksi Perpajakan secara parsial tidak berpengaruh terhadap Kepatuhan Wajib Pajak Kendaraan Bermotor. Hal tersebut terbukti dari nilai signifikansi pada variabel Sanksi Perpajakan yaitu sebesar $0,842(0,842>0,05)$. 
Uji Koefisien Determinasi

Koefisien Determinasi dalam penelitian ini digunakan untuk mengukur seberapa besar kemampuan model dalam menerangkan variasi variabel dependennya. Hasil Koefisien Determinasi dapat dilihat pada tabel 4.7 sebagai berikut:

Tabel 4.7

Hasil Koefisien Determinasi

Model Summary ${ }^{b}$

\begin{tabular}{l|c|c|c|r|}
\hline Model & R & R Square & $\begin{array}{c}\text { Adjusted R } \\
\text { Square }\end{array}$ & $\begin{array}{c}\text { Std. Error of } \\
\text { the Estimate }\end{array}$ \\
\hline 1 &, $405^{\text {a }}$ &, 164 &, 129 & 3,512 \\
\hline
\end{tabular}
a. Predictors: (Constant), SP, NS, KWP, KP
b. Dependent Variable: KPT

Sumber: Output SPSS23

Berdasarkan tabel 4.7 diatas nilai Adjusted $\mathrm{R}$ Square sebanyak 0,129 yang artinya bahwa dalam model regresi yang digunakan yakni variabel independen yakni Norma Subjektif, Kesadaran Wajib Pajak, Kualitas Pelayanan dan Sanksi Perpajakan dapat menjelaskan variabel independen yakni Kepatuhan Wajib Pajak Kendaraan Bermotor 0,129 atau $12,9 \%$. Sedangkan sisanya yakni $88,1 \%$ dijelaskna oleh variabel lain yang tidak digunakan dalam penelitian ini.

Pembahasan

Berdasarkan hasil analisis data maka dapat di uraikan pembahasan dalam penelitian ini sebagai berikut:

Norma Subjektif, Kesadaran Wajib Pajak, Kualitas Pelayanan dan Sanksi Perpajakan berpengaruh secara simultan terhadap Kepatuhan Wajib Pajak Kendaraan Bermotor.

Dalam penelitian ini variabel Norma Subjektf, Kesadaran Wajib Pajak, Kualitas Pelayanan dan Sanksi Perpajakan berpengaruh secara simultan terhadap Kepatuhan Wajib Pajak Kendaraan Bermotor .Hal tersebut dilihat dari nilai signifikan yang diperoleh sebesar $0,002(0,002<0,05)$ dengan nilai Fhitung yang dihasilkan sebesar 10,188 nilai ini lebih besar daripada nilai Ftabel sebesar 2,57 (10,188 > 2,57).

2. Pengaruh Norma Subjektif terhadap Kepatuhan Wajib Pajak Kendaraan Bermotor

Dalam penelitian ini Norma Subjektif (X1) yang menghasilkan nilai signifikansi sebesar 0,104 jika dibandingkan dengan tingkat signifikansi nilai tersebut lebih besar dari 0,05. Hal ini menyatakan bahwa variabel Norma Subjektif (X1) tidak berpengaruh secara parsial terhadap variabel Kepatuhan Wajib Pajak Kendaraan Bermotor (Y).

Hasil penelitian ini tidak sejalan dengan dengan penelitian yang dilakukan oleh Alvin (2014) dan Rita Yuliana (2014) yang menunjukkan bahwa Norma Subjektif berpengaruh secara signifikan terhadap kepatuhan wajib pajak. Hal tersebut terjadi karena seseorang cenderung untuk melakukan kewajiban perpajakannya ketika mereka sadar bahwa suatu hal termasuk dalam memenuhi kewajiban membayar pajak memang penting untuk dilakukan, bukan 
dikarenakan oleh adanya dorongan dari pihak luar.

Pengaruh Kesadaran Wajib Pajak terhadap Kepatuhan Wajib Pajak Kendaraan Bermotor

Dalam penelitian ini Kesadaran Wajib Pajak (X2) menghasilkan nilai signifikansi sebesar 0,028 jika dibandingkan dengan tingkat signifikansi nilai tersebut lebih kecil dari 0,05. Hal ini menyatakan bahwa variabel Kesadaran Wajib Pajak (X2) berpengaruh secara parsial terhadap variabel $\mathrm{Y}$.

Penelitian tersebut sejalan dengan penelitian Efendy, dkk (2015) yang menyatakan bahwa Kesadaran Wajib Pajak berpengaruh positif terhadap Kepatuhan Wajib Pajak. Dengan adanya kesadaran wajib pajak yang tinggi akan memicu wajib pajak menjadi patuh, semakin wajib pajak sadar akan pentingnya membayar pajak yang diperuntukkan untuk pembangunan daerah, masyarakat akan cenderung meningkatkan kepatuhan wajib pajak dalam membayar pajak kendaraan bermotor dan memenuhi kewajiban perpajakannya dengan disiplin dan tanpa paksaan.

Pengaruh Kualitas Pelayanan terhadap Kepatuhan Wajib Pajak Kendaraan Bermotor

Dalam penelitian ini Kualitas Pelayanan (X3) yang menghasilkan nilai signifikansi sebesar 0,024 jika dibandingkan dengan tingkat signifikansi nilai tersebut lebih kecil dari 0,05. Hal ini menyatakan bahwa variabel Kualitas Pelayanan berpengaruh secara parsial terhadap variabel Y.

Penelitian ini sejalan dengan penelitian yang dilakukan oleh Ilhamsyah, dkk (2016) yang menunjukkan bahwa Kualitas Pelayanan berpengaruh signifikan terhadap Kepatuhan Wajib Pajak Kendaraan Bermotor. Hal ini menunjukkan bahwa dalam melakukan pelayanan terhadap wajib pajak kendaraan bermotor kantor SAMSAT Kabupaten Pemalang sudah baik serta sesuai dengan harapan wajib pajak, sehingga wajib pajak merasa nyaman dan tertarik untuk melaksanakan kewajiban perpajakannya.

Pengaruh Sanksi Perpajakan terhadap Kepatuhan Wajib Pajak Kendaraan Bermotor

Dalam penelitian ini Sanksi Perpajakan (X4) yang menghasilkan nilai signifikansi sebesar 0,842 jika dibandingkan dengan tingkat signifikansi nilai tersebut lebih besar dari 0,05. Hal ini menyatakan bahwa variabel Kualitas Pelayanan (X4) tidak berpengaruh secara parsial terhadap variabel $\mathrm{Y}$.

Hasil penelitian ini tidak sejalan dengan dengan penelitian yang dilakukan oleh Effendy (2015) bahwa Sanksi perpajakan berpengaruh positif terhadap Kepatuhan Wajib Pajak. Sanksi yang diberikan untuk pelanggar sudah sesuai dan sepatutnya diberikan bagi pelanggar. Akan tetapi masih banyak masyarakat yang kurang benar melaksanakan kewajiban pajak kendaraan bermotornya. Sebagian masyarakat memandang bahwa sanksi akan merugikannya, akan tetapi tidak 
membuat masyarakat jera, hal itu dikarenakan faktor ekonomi yang membuat masyarakat tidak tepat waktu dalam melaksanakan kewajiban perpajakannya.

\section{KESIMPULAN DAN SARAN}

Kesimpulan

Berdasarkan hasil analisis data dan pembahasan yang telah dijelaskan pada bab-bab sebelumnya dalam penelitian ini, maka dapat disimpulkan sebagai berikut:

Norma Subjektif, kesadaran wajib pajak, kualitas pelayanan dan sanksi perpajakan berpengaruh secara simultan terhadap kepatuhan wajib pajak kendaraan bermotor Hal tersebut dilihat dari nilai signifikan yang diperoleh sebesar $0,002(0,002<$ $0,05)$.

Norma Subjektif tidak berpengaruh signifikan terhadap kepatuhan wajib pajak kendaraan bermotor hal tersebut dilihat dari nilai signifikansi sebesar 0,104 jika dibandingkan dengan tingkat signifikansi nilai tersebut lebih besar dari 0,05.

Kesadaran wajib pajak berpengaruh signifikan terhadap kepatuhan wajib pajak kendaraan bermotor. Hal tersebut dilihat dari nilai signifikansi sebesar 0,028 jika dibandingkan dengan tingkat signifikansi nilai tersebut lebih kecil dari 0,05.

Kualitas Pelayanan pajak berpengaruh signifikan terhadap kepatuhan wajib pajak kendaraan bermotor. Hal tersebut dilihat dari nilai signifikansi sebesar 0,024 jika dibandingkan dengan tingkat signifikansi nilai tersebut lebih kecil dari 0,05.
Sanksi Perpajakan tidak berpengaruh secara signifikan terhadap kepatuhan wajib pajak kendaraan bermotor. Hal tersebut dilihat dengan nilai signifikansi sebesar 0,842 jika dibandingkan dengan tingkat signifikansi nilai tersebut lebih besar dari 0,05.

Norma Subjektif, kesadaran wajib pajak, kualitas pelayanan dan sanksi perpajakan berpengaruh sebesar $12,9 \%$ sedangkan sisanya yakni sebesar $88,1 \%$ dipengaruhi oleh variabel lain diluar penelitian ini.

\section{Saran}

Berdasarkan kesimpulan di atas, penulis akan memberikan saran yang bermanfaat sebagai berikut:

Kepada Kantor SAMSAT Kabupaten Pemalang diharapkan agar meningkatkan sosialisasi mengenai peraturan perpajakan terkait pajak kendaraan bermotor kepada organisasi profesi dan meningkatkan kualitas pelayanan pajak agar kepatuhan wajib pajak meningkat dan target penerimaan pajak dapat terealisasi.

Untuk pemerintah diharapkan lebih meningkatkan kepercayaan masyarakat terhadap instansi perpajakan, diharapkan lebih menanamkan nilai-nilai kejujuran dan lebih menerapkan kode etik pegawai pajak melalui pengawasan intern yang telah ada di dalam setiap Kantor Pelayanan Pajak serta pemberian sanksi yang tegas terhadap petugas pajak yang diketahui melanggar kode etik pegawai pajak sehingga dapat memberikan efek jera.

Diharapkan bagi peneliti yang akan datang untuk memperluas 
lagi obyek penelitian serta faktor-faktor yang mempengaruhi kepatuhan wajib pajak kendaraan bermotor serta menambah variabel independen atau penggunaan variabel independen lain seperti kewajiban moral, sosialisasi perpajakan, tingkat penghasilan wajib pajak.

\section{DAFTAR PUSTAKA}

Ardyanto, A. A., \& Utaminingsih, N. S. (2014). Pengaruh Sanksi Pajak dan Pelayanan Aparat Pajak Terhadap Kepatuhan Wajib Pajak Dengan Preferensi Risiko Sebagai Variabel Moderasi. Accountung Analysis Journal, Universitas Negeri Semarang Vol.3 No.2.

Alvin, A. (2014). Pengaruh Sikap, Norma Subyektif, dan Kontrol Perilaku yang Dipersepsikan Terhadap Kepatuhan Pajak Wajib Pajak Badan. TAX \& ACCOUNTING REVIEW, VOL. 4, NO.1 .

Arnanto, T. Y. (2017). Pengaruh Pemahaman dan Pengetahuan Wajib Pajak Tentang Peraturan Perpajakan, Kualitas Pelayanan, Sanksi Perpajakan, dan Kesadaran Wajib Pajak Terhadap Kepatuhan Wajib Pajak Kendaraan Bermotor (Studi Kasus Pada SAMSAT Kota Semarang I). Jurnal Fakultas Ekonomi \& Bisnis, Universitas Dian Nuswantoro Semarang.

Badan Pusat Statistik. (2017). Kabupaten Pemalang dalam Angka 2017. Pemalang: BPS Kabupaten Pemalang. Dharma, dkk. (2014). Pengaruh Kesadaran Wajib Pajak, Sosialisasi Perpajakan, dan Kualitas Pelayanan Pada Kepatuhan Wajib Pajak. EJurnal Akuntansi Universitas Udayana 6.1 .

Dharmawan, G. B., \& Baridwan, Z. (2015). Pengaruh Norma Subyektif, Pemahaman Terhadap Sistem Self Assessment, Dan Kualitas Pelayanan Terhadap Kepatuhan Perpajakan . Universitas Brawijaya Malang.

Efendy, dkk. (2015). Pengaruh Biaya Kepatuhan, Sanksi Perpajakan dan Kesadaran Wajib Pajak Terhadap Kepatuhan Wajib Pajak (Studi Pada Wajib Pajak Kendaraan Bermotor Di Upt Dinas Pendapatan Provinsi Jawa Timur Malang Kota). Jurnal Administrasi Bisnis - Perpajakan (JAB), Vol. 5 No. 2.

Elia Mustikasari. (2007). Kajian Empiris Tentang Kepatuhan Wajib Pajak Badan Di Perusahaan Industri Pengolahan Di Surabaya. Simposium Nasional Akuntansi $X$.

Faiza, N. (2017). Pengaruh Pemahaman Peraturan Perpajakan, Kesadaran Wajib Pajak, Kualitas Pelayanan Dan Sanksi Perpajakan Terhadap Kepatuhan Wajib Pajak. Artikel Ilmiah STIE Perbanas Surabaya. 
Fuadi, A. O., \& Mangonting, Y. (2013). Pengaruh Kualitas Pelayanan Petugas Pajak, Sanksi Perpajakan dan Biaya Kepatuhan Pajak Terhadap Kepatuhan Wajib Pajak UMKM. Tax \& Accounting Review, Vol 1 No.1.

Ghozali, I. (2016). Aplikasi Analisis Multivariate Dengan Program IBM SPSS 23. Universitas Diponegoro. Hermawan, \& Arisman, A. (2016). Pengaruh Kualitas Pelayanan Pajak Terhadap Kepatuhan Wajib Pajak Kendaraan Bermotor Di SAMSAT Kota Palembang. Jurnal Akuntansi STIE Multi Data.

Ilhamsyah, dkk. (2016). Pengaruh Pemahaman dan Pengetahuan Wajib Pajak Tentang Peraturan Perpajakan, Kesadaran Wajib Pajak, Kualitas Pelayanan, dan Sanksi Perpajakan Terhadap Kepatuhan Wajib Pajak Kendaraan Bermotor (Studi Samsat Kota Malang). Jurnal Perpajakan (JEJAK), Vol. 8 No. 1.

Isra Yenti, dkk. (2017). Pengaruh Kesadaran Wajib Pajak, Sanksi Pajak, Kualitas Layanan Fiskus Terhadap Kepatuhan Wajib Pajak Kendaraan Bermotor Di Kabupaten Pasaman. Jurnal STKIP PGRI Sumatera Barat.

Irianingsih, E. (2015). Pengaruh Kesadaran Wajib Pajak, Pelayanan Fiskus Dan Sanksi Administrasi Pajak Terhadap Kepatuhan Wajib Pajak Dalam Membayar Pajak Kendaraan Bermotor Di Kantor Pelayanan Pajak Kendaraan SAMSAT Sleman. Artikel Program Studi Akuntansi Fakultas Ekonomi UNIVERSITAS PGRI YOGYAKARTA.

Jauhari, H. (2010). Panduan Penulisan Skripsi Teori dan Aplikasi. Bandung: Pustaka Setia.

Khasanah, S. N. (2014). Pengaruh Pengetahuan Perpajakan, Modernisasi Sistem Administrasi Perpajakan, dan Kesadaran Wajib Pajak Terhadap Kepatuhan Wajib Pajak pada Kantor Wilayah Direktorat Jenderal Pajak Daerah Istimewa Yogyakarta Tahun 2013,. Skripsi Fakultas Ekonomi Univesitas Negeri Yogyakarta.

Mardiasmo. (2013). Perpajakan Edisi Revisi. Yogyakarta: Andi.

Martono, N. (2012). Metode Penelitian Kuantitatif Analisis Isi dan Analisis Data Sekunder. Edisi Revisi. Jakarta: Rajawali Pers.

Novelia, K. R. (2009). Pengaruh Kualitas Pelayanan Terhadap Kepuasan Wajib Pajak (Suatu Studi untuk Pajak Kendaraan Bermotor di Sistem Administrasi Manunggal Dibawah Satu Atap Kota Depok). Universitas Indonesia.

Nugroho, dkk. (2016). Pengaruh Kesadaran Wajib Pajak Dan Pengetahuan Perpajakan Wajib Pajak Terhadap Kepatuhan Wajib Pajak Dalam Membayar Pajak Penghasilan (studi kasus pada KPP Semarang Candi). Journal Of Accounting, Volume 2 No.2. 
Rahayu, S. K. (2017). Perpajakan (Konsep dan Aspek Formal). Bandung: Rekayasa Sains.

Republik indonesia. (2009). Undang-Undang No.20 Tahun 2009 tentang Pajak Daerah dan Retribusi Daerah. Jakarta: Lembaga Negara RI Tahun 2009, Sekretariat Negara Jakarta.

Safri, R. D. (2013). Pengaruh Kesadaran Wajib Pajak Terhadap Kepatuhan Wajib Pajak Orang Pribadi Yang Melakukan Pekerjaan Bebas (Studi Di Wilayah KPP Pratama Yogyakarta). Tugas Akhir Fakultas Ekonomi Universitas Negeri Yogyakarta.

Santoso, S. (2015). Menguasai Statistik Parametrik. Jakarta: Elex Media Komputindo.

Sari, dkk. (2013). Faktor-Faktor Yang Mempengaruhi Kepatuhan Wajib Pajak Dalam Membayar Pajak Kendaraan Bermotor (PKB) Di Unit Pelayanan Pendapatan Provinsi (UPPP) Kabupaten Seluma. Ekombis Review.

Sagita, R. K. (2017). Norma Subjektif dan Kualitas Pelayanan Terhadap Kepatuhan Wajib Pajak Kendaraan Bermotor Pada Kantor Samsat wilayah 1 Kota Makassar. Universitas Hasanudin Makassar. Sekaran, U. (2006). Metodologi Penelitian Untuk Bisnis Buku 2 Edisi 4. Jakarta: Salemba Empat.

Setiawan, \& Muliari, N. K. (2009). Pengaruh Persepsi Tentang Sanksi Perpajakan dan Kesadaran Wajib Pajak Pada Kepatuhan Pelaporan Wajib Pajak Orang Pribadi Di Kantor Pelayanan Pajak Pratama Denpasar Timur. Jurnal Akuntansi, Fakultas Ekonomi.

Siahaan, M. P. (2013). Pajak Daerah dan Retribusi Daerah. Jakarta: Rajawali Pers. Suandy, E. (2011). Perencanaan Pajak Edisi 5. Jakarta: Salemba Empat.

Sudarso, A. (2016). Manajemen Pemasaran Jasa Perhotelan. Yogyakarta: Deepublish. Sugiyono, (2015). Statistika Untuk Pengukuran. Bandung, Alfabeta.

Sumaryono, E. (2012). Etika Profesi Hukum. Yogyakarta: Kanisius.

Suryani, L. (2017). Pengaruh Sikap, Norma Subjektif, dan Kontrol Perilaku Persepsian Terhadap Kepatuhan Wajib Pajak Orang Pribadi Di Daerah Istimewa Yogyakarta Dengan Niat Mematuhi Pajak Sebagai Variabel Pemoderasi. Skripsi Fakultas Ekonomi Universitas Negeri Yogyakarta.

Wardani, D. K., \& Rumiyatun. (2017). Pengaruh Pengetahuan Wajib Pajak, Kesadaran Wajib Pajak, Sanksi Pajak Kendaraan Bermotor, Dan Sistem SAMSAT Drive Thru Terhadap Kepatuhan Wajib Pajak Kendaraan Bermotor (Studi kasus WP PKB roda empat di Samsat Drive Thru Bantul). Jurnal Akuntansi Vol. 5 No 1. 
Warta DPRD Jateng (2017). Dipetik Januari 18, 2018, dari dprd. jatengprov.go.id/post/uppd-pemalang-mampu- realisasikan-75-persen-dari-target$\mathrm{pad}$

Yasa, I. P., \& Jati, I. K. (2017). Pengaruh Kondisi Keuangan Wajib Pajak Sebagai Pemoderasi Pengaruh Sanksi Perpajakan dan Kesadaran Wajib Pajak Pada Kepatuhan Wajib Pajak. E-Jurnal Akuntansi Universitas Udayana, Vol.19.2.

Yuliana, I. d. Pengaruh Sikap, Norma Subjektif dan Keadilan Pajak Terhadap Kepatuhan Wajib Pajak Orang Pribadi Di KPP Pratama Madiun. Jurnal Akuntansi dan Pendidikan, Vol.3 No.2.

Yusuf Chusaeri, d. (2017). Pengaruh Pengetahuan Dan Pemahaman Wajib Pajak Tentang Peraturan Perpajakan, Kesadaran Wajib Pajak, Kualitas Pelayanan, Dan Sanksi Perpajakan Terhadap Kepatuhan Wajib Pajak (Studi Samsat Kota Batu). Jurnal Fakultas Ekonomi, Universitas Islam Malang. 